\title{
Greenhouse gas emission associated with sugar production in southern Brazil
}

\author{
Eduardo Barretto de Figueiredo*, Alan Rodrigo Panosso ${ }^{\dagger}$, Rangel Romão ${ }^{\dagger}$ and Newton La Scala Jr ${ }^{\dagger}$
}

\begin{abstract}
Background: Since sugarcane areas have increased rapidly in Brazil, the contribution of the sugarcane production, and, especially, of the sugarcane harvest system to the greenhouse gas emissions of the country is an issue of national concern. Here we analyze some data characterizing various activities of two sugarcane mills during the harvest period of 2006-2007 and quantify the carbon footprint of sugar production.
\end{abstract}

Results: According to our calculations, $241 \mathrm{~kg}$ of carbon dioxide equivalent were released to the atmosphere per a ton of sugar produced (2406 kg of carbon dioxide equivalent per a hectare of the cropped area, and $26.5 \mathrm{~kg}$ of carbon dioxide equivalent per a ton of sugarcane processed). The major part of the total emission (44\%) resulted from residues burning; about 20\% resulted from the use of synthetic fertilizers, and about 18\% from fossil fuel combustion.

Conclusions: The results of this study suggest that the most important reduction in greenhouse gas emissions from sugarcane areas could be achieved by switching to a green harvest system, that is, to harvesting without burning.

\section{Background}

Increasing atmospheric greenhouse gases (GHG) and its relation to human activities have pressured the productive sector to mitigate its GHG emission [1]. Developing country-specific emission factors and activity data have been a tough challenge particularly for non-Annex I countries which are recognized mostly as certain groups of developing countries that are vulnerable to the adverse impacts of climate change. Therefore the demand for assistance for non-Annex I countries to improve their inventories is likely to rise and should be effectively made [2]. Among the main practices that have caused national concern in Brazil, the harvest system is highlighted, especially in sugarcane agricultural areas, which in most regions are still based on residues burning. In contrast, the so-called green harvest, without burn, keeps large amounts of crop residues in soil surface [3].

Sugarcane residues represents $11 \%$ of the worldwide agricultural residues [4], and while sugarcane areas have increased rapidly in Brazil, few papers quantify its impact on air quality due to the land use, especially considering

\footnotetext{
* Correspondence: eduardobfigueiredo@hotmail.com

1 FCAV/UNESP, Departamento de Ciências Exatas,.Via de acesso Prof. Paulo D.

Castellane s/n. 14884-900, Jaboticabal, São Paulo, Brazil

+ Contributed equally

Full list of author information is available at the end of the article
}

the burning practice [5-7]. Brazil is the biggest worldwide sugarcane grower with a 622 millions ton production (2008/2009) concentrated in 7.8 millions of hectares [8]. Those are mostly driven to ethanol (55\%) and sugar (45\%) derivatives, while sugarcane industrial process generate also $11.3 \mathrm{TWh}$ of electric energy produced in the power plants in most of the sugarcane mills, corresponding to $3 \%$ of all electric energy consumed in the country [8]. Sugarcane is one of the world's major food-producing crops providing about $75 \%$ of the sugar for human consumption [9]. Projections indicate the biomass importance in near future that will provide up to $20 \%$ of all worldwide energy used in the end of 21 century [10]. Adding efforts to reduce emission from energy and deforestation sectors, it is also a top priority to implement innovative programs that promote mitigation in the agricultural and livestock sectors [11].

The goal of this work was to determine a scope for sugarcane mills emissions within its own boundary and quantify the GHG emissions sources related to the sugarcane production in agricultural sector in Brazil. It was applied the Intergovernmental Panel on Climate Change (IPCC) methodology [12], chapter $11, \mathrm{~N}_{2} \mathrm{O}$ emissions from managed soils, and $\mathrm{CO}_{2}$ emissions from lime and urea application, chapter 2 Generic methodologies applicable to multiple land-use categories and The First Bra- 
zilian Inventory to Mobile Combustion [13]. It was considered the total sugar production in order to determine the carbon footprint in terms of carbon dioxide equivalent $\left(\mathrm{CO}_{2} \mathrm{eq}\right)$ released to the atmosphere per area, ton of cultivated sugarcane and sugar produced.

\section{Results and Discussion}

Figure 1 presents the partition of GHG emission for each emission source considered in this study. Based on the scenario and studied year, total company's GHG emission was 164,878 ton of $\mathrm{CO}_{2}$ eq corresponding to 2.41 ton of $\mathrm{CO}_{2}$ eq emitted for each cropped hectare. Some authors showed emission of 3.24 ton of $\mathrm{CO}_{2} \mathrm{eq} \mathrm{ha}{ }^{-1}$ considering $60 \%$ of area harvested with burning practice and emission related to fertilizers, herbicides and pesticides manufacturing phase incorporated in this amount [14] while in our scope it was considered emissions related to company's boundary emissions, only. Others authors consider also emissions from the manufacture and distribution of agricultural inputs used for Brazilian sugarcane production presenting a net contribution of $\mathrm{CO}_{2}$ from the sugarcane agro industry to the atmosphere as 3.12 ton per ha [15]. On the other hand, results have shown an average from 0.32 ton $\mathrm{C} \mathrm{ha-1} \mathrm{yr}^{-1}$ accumulated in the first $20 \mathrm{~cm}$ depth to 1.95 ton $\mathrm{C} \mathrm{ha}^{-1} \mathrm{yr}^{-1}$ for the top $40 \mathrm{~cm}$ layer referring to green harvest adoption instead of burning, corresponding to as much as 7.15 ton $\mathrm{CO}_{2} \mathrm{eq} \mathrm{ha} \mathrm{hr}^{-1} \mathrm{yr}^{-1}$. This could be effectively considered a $\mathrm{CO}_{2}$ sequestration from atmosphere due the conversion of burned to green harvest [11], which despite the uncertain, has the potential to mitigate all GHG emission of this sector.

Residues burning accounted for 72,462 ton $\mathrm{CO}_{2} \mathrm{eq}$, around $44 \%$ of total emission, equivalent to 1.21 ton of $\mathrm{CO}_{2} \mathrm{eq}$ for each burnt hectare, being $72 \%$ of this associ-

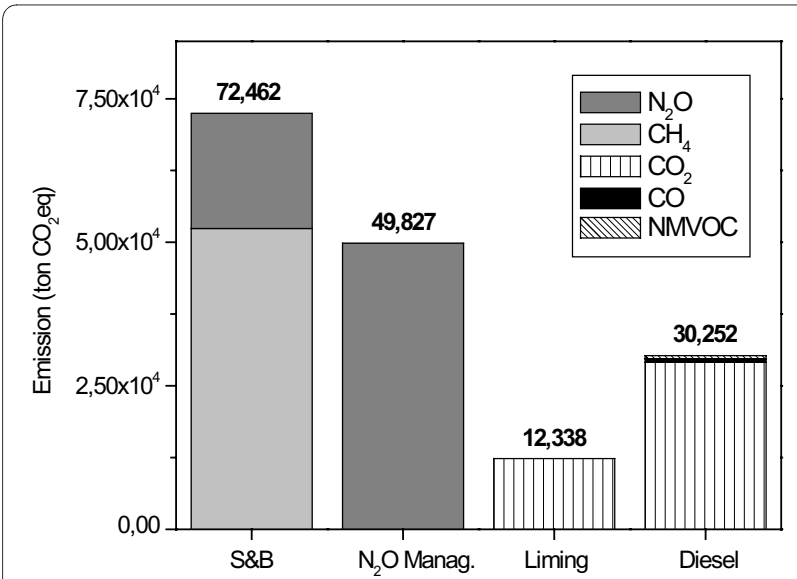

Figure 1 Total GHG emissions, 2006/2007 season per source, sugarcane burning, $\mathrm{N}_{2} \mathrm{O}$ from managed soils, liming application and diesel use (ton $\mathrm{CO}_{2} \mathrm{eq}$ ). ated to $\mathrm{CH}_{4}$ emission only. In our inventory $\mathrm{CO}_{2}$ and $\mathrm{CO}$ emissions were not included as net GHG emission to atmosphere when the crop residue burning is considered. Some authors also do not compute those gases as net emission when referred to the burning practice $[12,16]$. $\mathrm{CO}_{2}$ sunk by sugarcane crops in following year compensates the amount of $\mathrm{CO}_{2}$ and $\mathrm{CO}$ (that once in atmosphere rapidly transforms in $\mathrm{CO}_{2}$ ) emitted by burning. Computing the total $\mathrm{CO}_{2}$ captured by photosynthesis relative to the 2006/2007 crop season with area of 68,541 ha, there is something around 5,133,212 ton of $\mathrm{CO}_{2}$, equivalent to 74.9 ton of $\mathrm{CO}_{2}$ ha-1 $^{-1}$ sunk by sugarcane crops from atmosphere. This value is comparable to the one presented for sugarcane crops, with an amount of 107.2 ton of $\mathrm{CO}_{2}$ ha $^{-1}$ year $^{-1}[17]$.

Direct and indirect $\mathrm{N}_{2} \mathrm{O}$ emission due to the synthetic fertilizers use, organic composts and harvest residues caused an emission of 49,827 ton of $\mathrm{CO}_{2} \mathrm{eq}$, corresponding to $30 \%$ of the total emission. Fossil fuel combustion (diesel use) and lime application contributed with 30,252 and 12,338 ton of $\mathrm{CO}_{2}$ eq, respectively, mostly due to $\mathrm{CO}_{2}$ only. Substitution from diesel to biodiesel has been cited as an alternative to reduce net $\mathrm{CO}_{2}$ emission in this sector [17]. Also, $\mathrm{CO}_{2}$ emission due to diesel use could be reduced from 15 to $29 \%$ by alternative tillage systems i.e. reduced tillage, as a consequence of fuel savings [18].

Figure 2 presents the partition of direct and indirect $\mathrm{N}_{2} \mathrm{O}$ emissions in terms of their sources. Organic fertilizers applied on soil resulted in 7,678 ton of $\mathrm{CO}_{2} \mathrm{eq}$, corresponding to $15 \%$ of total $\mathrm{N}_{2} \mathrm{O}$ emitted in this sector. Synthetic fertilizers application resulted in 33,181 ton of $\mathrm{CO}_{2}$ eq (67\%) and it considers only the use emission, not

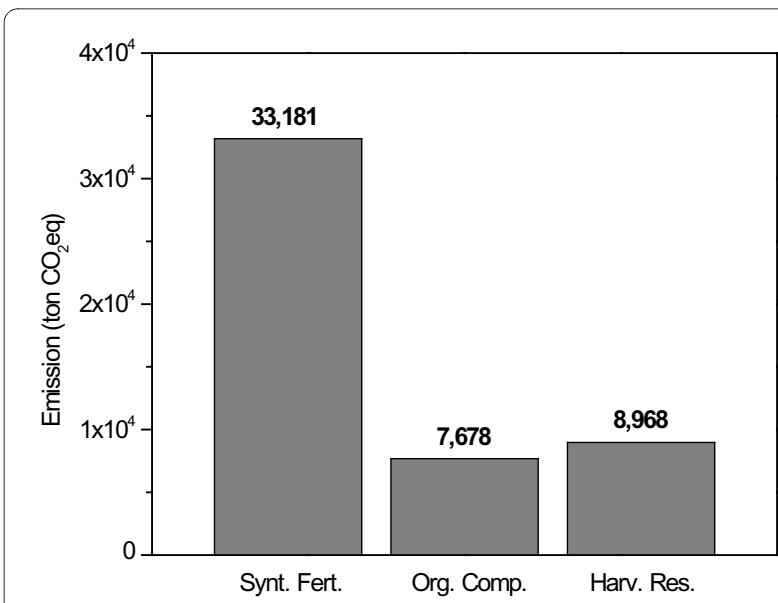

Figure $2 \mathrm{~N}_{2} \mathrm{O}$ direct and indirect emissions from managed soils converted in $\mathrm{CO}_{2}$ eq referring to synthetic fertilizer use, organic composts applied on soils and harvest residue. 
the ones associated to the fertilizer production. The application of chemical or organic fertilizers on soil can stimulate $\mathrm{N}_{2} \mathrm{O}$ and $\mathrm{NO}$ production via nitrification (aerobic) and denitrification (anaerobic) biochemical processes $[19,20]$. The input of organic fertilizers to agricultural soils is considered an important source of $\mathrm{N}_{2} \mathrm{O}$ [21] with both chemical and organic fertilizer applications being the major sources of $\mathrm{NH}_{3}$ [9,22,23]. In our inventory these were some of the mainly sources of GHG emission to atmosphere, believing that such aspect is representative of sugarcane production areas.

Residues from sugarcane remained on field resulted in 8,968 ton of $\mathrm{CO}_{2} \mathrm{eq}$, coming from residual $\mathrm{N}$ content which is converted to $\mathrm{N}_{2} \mathrm{O}$ through nitrification, aerobic microbial oxidation of ammonium to nitrate and denitrification process which is the anaerobic microbial reduction of nitrate to nitrogen gas $\left(\mathrm{N}_{2}\right)$. Nitrous oxide is a gaseous intermediate in the reaction sequence of denitrification and a by-product of nitrification that is ultimately released into the atmosphere [12]. The application of nitrification inhibitors has been suggested as an option for decreasing $\mathrm{N}$-fertilizer use and consequently such emission [24]. Strategies that increase N-fertilizer efficiency, reducing $\mathrm{N}_{2} \mathrm{O}$ emission have also been suggested by several authors [24-26].

Table 1. presents estimations of GHG emission per kilogram of sugar produced, per hectare and per ton of sugarcane produced. According to this study each ton of sugarcane processed released $26.5 \mathrm{~kg} \mathrm{CO}$ eq to atmosphere, resulting $241 \mathrm{~kg}$ of $\mathrm{CO}_{2} \mathrm{eq}$ for each ton of sugar produced. Emission value for sugar beet production (Life Cycle Assessment - LCA) suggests an emission of $900 \mathrm{~kg}$ of $\mathrm{CO}_{2}$ eq per ton of sugar produced [27]. LCA should be a suitable tool to assess the environmental impact associated with agricultural production [27], but this provides different methodologies to compare GHG emission in agricultural sector. In Brazil, some authors presented amounts of $222 \mathrm{~kg} \mathrm{CO}_{2}$ eq ton ${ }^{-1}$ of sugar in the so-called organic production, without burn and without synthetic fertilizers N application [28]. That study considered emissions related to sugar transport, energy imbed in the equipments and agricultural machines and also emissions

Table 1: Emission ratio, $\mathrm{kg} \mathrm{CO}_{2}$ eq per ton of sugar, $\mathrm{kg} \mathrm{CO}_{2} \mathrm{eq}$ per hectare and $\mathrm{kg} \mathrm{CO} \mathrm{CO}_{2}$ eq per ton of sugarcane

\begin{tabular}{ccc}
\hline \multicolumn{3}{c}{ Emission Ratio* } \\
\hline $\mathrm{kg} \mathrm{CO}_{2}$ eq ton ${ }^{-1}$ sugar & $\mathrm{kg} \mathrm{CO}_{2}$ eq ha-1 $\mathrm{kg} \mathrm{CO}_{2}$ eq ton ${ }^{-1}$ sugarcane \\
\hline 241 & 2,406 & 26.5 \\
\hline
\end{tabular}

*kg: kilogram, $\mathrm{CO}_{2}$ eq: Carbon dioxide equivalent, ha: hectare. related to production of chemical supplies, resulting amounts of $34.08 \mathrm{~kg} \mathrm{CO}$ eq per ton of sugarcane processed, a reduction of $32 \%$ in GHG emission when compared to conventional practices that resulted in $50.44 \mathrm{~kg}$ $\mathrm{CO}_{2}$ eq, considering the same scope [29].

\section{Conclusions}

Considering the studied scenario, with $87 \%$ of the total area managed with burning practice and $13 \%$ of green harvest, GHG emission ratio was $241 \mathrm{~kg} \mathrm{CO}_{2} \mathrm{eq}$ ton $^{-1}$ of produced sugar. Each hectare of sugarcane cropped transferred to the atmosphere $2,406 \mathrm{~kg}$ of $\mathrm{CO}_{2}$ eq per year. This indicate that a more sustainable agricultural production systems as conservation tillage and direct planting during the re-planting season, as well as rationalizing the $\mathrm{N}$ fertilizers use might be achieved to reduce GHG emissions in sugarcane areas. The total sugarcane production of 6,221,025 ton resulted in an emission ratio of $26.5 \mathrm{~kg}$ of $\mathrm{CO}_{2}$ eq per ton of sugarcane processed. Considering only emissions from application and not emission from production of synthetic fertilizers $\mathrm{N}$ applied to soils, each kilogram used transfers to the atmosphere $6.45 \mathrm{~kg} \mathrm{CO}_{2}$. Sugarcane field burning practice impacted on 1.21 ton of $\mathrm{CO}_{2}$ eq per hectare burnt, considering only GHG net emissions. Responsible for $44 \%$ of total GHG emission, the conversion of sugarcane burning system to green harvest could reduce emissions in this sector. Considering actual production process, the company emission baseline to $2006 / 2007$ season was 164,878 ton of $\mathrm{CO}_{2}$ eq. The mitigation of GHG emissions from sugarcane areas could be achieved either by reducing burning and fertilization practices or using soil as a carbon sink. Applications of standardized scope, emission factors and emissions boundaries within company's activities only, show be necessary to promote comparison among companies and GHG emission reduction.

\section{Methods}

To elaborate this work it was adopted the reference data of 2006/2007 informed by appropriated company sector, harvest period (from May 2006 to April 2007) from a sugarcane mill located in the southern Brazil, northeast region of São Paulo State, Brazil. The total sugarcane cropped area of the studied sugarcane plants in the period was 68,541 hectares (ha), resulting in a sugarcane and sugar production of 6,221,025 and 684,850 ton, respectively for both mills. In this scope we did not consider emissions related to the production of any supply (synthetic fertilizers, cement, herbicides, pesticides, steel, etc.) considering it to each company the decision to provide its own inventory.

Estimates of how much $\mathrm{C}$ was stored by crops in one year was calculated by considering the total sugarcane 
dry mass content as $53 \%$, being $25 \%$ stalks, $12 \%$ trash, $4 \%$ green leaves and $12 \%$ roots [30]. Mill database informed an average sugarcane yield of 90.76 ton ha- ${ }^{-1}$. To convert carbon $(\mathrm{C})$ to carbon dioxide $\left(\mathrm{CO}_{2}\right)$ it was applied the $44 /$ 12 factor (1 kilogram of carbon correspond to $3.67 \mathrm{~kg}$ $\mathrm{CO}_{2}$ captured), considering the $\mathrm{C}$ content in sugarcane dry matter as $42.46 \%$ [31].

The net emission was related to residues burning in the field, methane $\left(\mathrm{CH}_{4}\right)$ and nitrous oxide $\left(\mathrm{N}_{2} \mathrm{O}\right)$, [12], direct and indirect $\mathrm{N}_{2} \mathrm{O}$ emissions from managed soils [12] and $\mathrm{CO}_{2}$ emissions referred to lime application. Emissions of $\mathrm{CO}_{2}$, carbon monoxide (CO), $\mathrm{CH}_{4}, \mathrm{~N}_{2} \mathrm{O}$, and NMVOC (non-methane volatile organic compounds) referred to the use of fossil fuel (total diesel consumption for all equipments and agricultural machines involved within production) were considered [13] according to Mobile Sources Brazilian National Inventory. All values were converted to $\mathrm{CO}_{2}$ equivalent $\left(\mathrm{CO}_{2} \mathrm{eq}\right)$ following the individual global warming potential for a period of 100 years for each gas, using 1 to $\mathrm{CO}_{2}$ [12], 3 to $\mathrm{CO}$ [32], 21 to $\mathrm{CH}_{4}$, 310 to $\mathrm{N}_{2} \mathrm{O}$ [12] and 3.4 to NMVOC (only to mobile combustion) [12]. Table 2. summarizes the scope considered in this work with partition in sector and emission sources.

\section{Agricultural residues burning}

The impact of residues burning in GHG emission took into account data from sugarcane crop varieties grown and harvested in the burnt areas only $(59,820 \mathrm{ha})$. Total sugarcane yield was $5,643,786$ ton in burned areas, corresponding to an average yield of 94.4 ton ha- ${ }^{-1}$. Average values of residue per yield ratio were accounted in $19 \%$ of the varieties cropped in the burned areas indicating a residue per yield ratio of 0.205 , resulting in an average of residue mass available to combustion of 19.3 ton per hectare. According to an extended review [33], the value of residues yield from different plant varieties in São Paulo state is around 19.1 ton ha-1. This is also similar to the amount found by other authors [34,35], of 18.2 ton of sugarcane residues per hectare. The combustion factor applied in this work was 0.80 [12].
The sugarcane residues burning result is not only $\mathrm{CO}_{2}$ emissions but also other GHG or precursors, including carbon monoxide $(\mathrm{CO})$, methane $\left(\mathrm{CH}_{4}\right)$, non-methane volatile organic compounds (NMVOC) and nitrogen $\left(\mathrm{N}_{2} \mathrm{O}, \mathrm{NO}_{\mathrm{x}}\right)$ species [36]. Usually in the cropland and grassland areas only non- $\mathrm{CO}_{2}$ emissions are considered, due to the assumption that those would be counterbalanced by $\mathrm{CO}_{2}$ removals from the subsequent re-growth of the vegetation within one year [1]. The same applies to $\mathrm{CO}$, as this is converted in $\mathrm{CO}_{2}$ rapidly once in atmosphere [1]. $\mathrm{NO}_{\mathrm{x}}$ emission was not considered as a net GHG because its global warming potential is very uncertain [1].

Different emission factors related to sugarcane residues burning have been registered in literature [37]. In this work it was used the ones suggested by IPCC, [12], Chapter 2, Generic Methodologies Applicable to Multiple Land-Use Categories (Equation 1). Those were 2.7 and 0.07 to $\mathrm{CH}_{4}$ and $\mathrm{N}_{2} \mathrm{O}$ (all values in $\mathrm{g} \mathrm{kg}^{-1}$ dry matter burnt) respectively [38].

$$
\mathrm{L}_{\text {fire }}=\mathrm{A} \times \mathrm{M}_{\mathrm{B}} \times \mathrm{C}_{\mathrm{f}} \times \mathrm{G}_{\mathrm{ef}} \times 10^{-3}
$$

$\mathrm{L}_{\text {fire }}=$ amount of greenhouse gas emissions from fire, tones of each GHG e.g., $\mathrm{CH}_{4}, \mathrm{~N}_{2} \mathrm{O}$.

$\mathrm{A}=$ burnt area, ha $^{-1}$

$M_{B}=$ mass of fuel available for combustion, 19.3 ton ha1 .

$\mathrm{C}_{\mathrm{f}}=$ combustion factor, dimensionless. (default value to agricultural residues, 0.80 ).

$\mathrm{G}_{\mathrm{ef}}=$ emission factor, $\mathrm{g} \mathrm{kg}_{1}$ dry matter burnt (default values 2.7 to $\mathrm{CH}_{4}$ and 0.07 to $\mathrm{N}_{2} \mathrm{O}$ )

\section{Direct and indirect emissions of nitrous oxide from managed soils}

In this analysis, the emission sources considered were nitrogen from synthetic fertilizers and organic composts applied on soils (filter cake and vinasse), in addition to the harvest residues (Equation 2 - Direct emissions and Equation 3 and 4 - indirect emissions). In order to account for the total amount of $\mathrm{N}$ synthetic fertilizer applied we adopted a standard nitrogen demand from

Table 2: GHG emissions sources considered

\begin{tabular}{ll}
\hline Sector & Emissions Source \\
\hline Agricultural & $\mathrm{GHG}$ emissions due agricultural residues. \\
& $\mathrm{N}_{2} \mathrm{O}$ direct and indirect emissions from managed soils. \\
& $\mathrm{CO}_{2}$ emissions due lime application. \\
Mobile Combustion (Diesel vehicle) & Emissions due fossil fuel use (diesel oil). \\
\hline
\end{tabular}

*GHG: Greenhouse gases, $\mathrm{N}_{2} \mathrm{O}$ : Nitrous oxide, $\mathrm{CO}_{2}$ : Carbon dioxide. 
sugarcane agricultural areas in our region [39], which is around $75 \mathrm{~kg}$ of nitrogen $(\mathrm{N}) \mathrm{ha}^{-1} \mathrm{year}^{-1}$. On the other hand, the amount of filter cake and vinasse applied in the production areas was informed by the company as $119,140,000 \mathrm{~kg}$ and 1,872,338,000 liters respectively. The $\mathrm{N}$ content used was 1.4 and $1.1 \%$, for filter cake and vinasse, respectively, and those values were informed by the company, after the characterization. The $\mathrm{N}$ content in the filter cake was based on $25 \%$ of its dry mass, while $\mathrm{N}$ content of vinasse was considered as being $0.368 \mathrm{~kg} \mathrm{~N} \mathrm{~m}^{-}$ ${ }^{3}$ applied [40].

Equation 2 (direct emissions)

$$
\mathrm{N}_{2} \mathrm{O}-\mathrm{N}_{\mathrm{N} \text { inputs }}=\left(\mathrm{F}_{\mathrm{SN}}+\mathrm{F}_{\mathrm{ON}}+\mathrm{F}_{\mathrm{CR}}\right) \times \mathrm{EF}_{1} \text {, }
$$

Where:

$\mathrm{N}_{2} \mathrm{O}-\mathrm{N}_{N \text { inputs }}=$ annual direct $\mathrm{N}_{2} \mathrm{O}-\mathrm{N}$ emissions from $\mathrm{N}$ inputs to managed soils, $\mathrm{kg} \mathrm{N}_{2} \mathrm{O}-\mathrm{Nyr}^{-1}$.

$\mathrm{F}_{\mathrm{SN}}=$ annual amount of synthetic fertilizer $\mathrm{N}$ applied, $\mathrm{kg} \mathrm{N} \mathrm{yr}^{-1}$.

$\mathrm{F}_{\mathrm{ON}}=$ Annual amounts of compost or organic $\mathrm{N}$ additions (filter cake and vinasse), $\mathrm{kg} \mathrm{N} \mathrm{yr}^{-1}$.

$\mathrm{F}_{\mathrm{CR}}=$ Annual amount of $\mathrm{N}$ in crop residues, $\mathrm{kg} \mathrm{N} \mathrm{yr}^{-1}$.

$\mathrm{EF}_{1}=$ Emission factor for $\mathrm{N}_{2} \mathrm{O}$ emissions from $\mathrm{N}$ inputs, kg $\mathrm{N}_{2} \mathrm{O}-\mathrm{N}$

(kg N input) $)^{-1}=0.01$

Equation 3 (indirect emission)

$\mathrm{N}_{2} \mathrm{O}$ from atmospheric deposition of $\mathrm{N}$ volatilized from managed soils

$\mathrm{N}_{2} \mathrm{O}_{(\text {ATD })}-\mathrm{N}=\left(\mathrm{F}_{\mathrm{SN}} \times \mathrm{Frac}_{\mathrm{GASF}}\right)+\left(\mathrm{F}_{\mathrm{ON}} \times \mathrm{Frac}_{\mathrm{GASM}}\right) \times \mathrm{EF}_{4}$.

$\mathrm{N}_{2} \mathrm{O}_{(\text {ATD })}-\mathrm{N}=$ annual amount of $\mathrm{N}_{2} \mathrm{O}-\mathrm{N}$ produced from atmospheric deposition of $\mathrm{N}$ volatilized from managed soils, $\mathrm{kg} \mathrm{N}_{2} \mathrm{O}-\mathrm{N} \mathrm{yr}^{-1}$

$\mathrm{F}_{\mathrm{SN}}=$ annual amount of synthetic fertilizer $\mathrm{N}$ applied to soils, $\mathrm{kg} \mathrm{N} \mathrm{yr}^{-1}$.

Frac $_{\text {GASF }}=$ fraction of synthetic fertilizer $\mathrm{N}$ that volatilizes as $\mathrm{NH}_{3}$ and $\mathrm{NO}_{\mathrm{x}}, \mathrm{kg} \mathrm{N}$ volatilized ( $\mathrm{kg}$ of $\mathrm{N}$ applied) ${ }^{-1}$. Default value 0.10

$\mathrm{F}_{\mathrm{ON}}=$ annual amount of compost and other organic $\mathrm{N}$

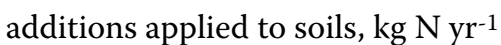

Frac ${ }_{G A S M}=$ fraction of applied organic $\mathrm{N}$ fertilizer materials $\left(\mathrm{F}_{\mathrm{ON}}\right)$ that volatilizes as $\mathrm{NH}_{3}$ and $\mathrm{NO}_{\mathrm{x}}, \mathrm{kg} \mathrm{N}$ volatilized ( $\mathrm{kg}$ of $\mathrm{N}$ applied or deposited) $)^{-1}$. Default value 0.20

$\mathrm{EF}_{4}=$ emission factor for $\mathrm{N}_{2} \mathrm{O}$ emissions from atmospheric deposition of $\mathrm{N}$ on soils and water surfaces, [kg $\mathrm{N}-\mathrm{N}_{2} \mathrm{O}\left(\mathrm{kg} \mathrm{NH}_{3}-\mathrm{N}+\mathrm{NO}_{\mathrm{x}}-\mathrm{N} \text { volatilized }\right)^{-1}$. Default value 0.01

Equation 4 (indirect emission)
$\mathrm{N}_{2} \mathrm{O}$ from $\mathrm{N}$ leaching/runoff from managed soils in regions where leaching/runoff occurs

$\mathrm{N}_{2} \mathrm{O}_{(\mathrm{L})}-\mathrm{N}=\left(\mathrm{F}_{\mathrm{SN}}+\mathrm{F}_{\mathrm{ON}}+\mathrm{F}_{\mathrm{CR}}\right) \times \mathrm{Frac}_{L E A C H} \times \mathrm{EF}_{5}$ (4)

$\mathrm{N}_{2} \mathrm{O}_{(\mathrm{L})}-\mathrm{N}=$ annual amount of $\mathrm{N}_{2} \mathrm{O}-\mathrm{N}$ produced from leaching and runoff of $\mathrm{N}$ additions to managed soils in regions where leaching/runoff occurs, $\mathrm{kg} \mathrm{N}_{2} \mathrm{O}-\mathrm{N} \mathrm{yr}^{-1}$.

$\mathrm{F}_{\mathrm{SN}}=$ annual amount of synthetic fertilizer $\mathrm{N}$ applied to soils in regions where leaching/runoff occurs, $\mathrm{kg} \mathrm{N} \mathrm{yr}^{-1}$.

$\mathrm{F}_{\mathrm{ON}}=$ annual amount of compost and other organic $\mathrm{N}$ additions applied to soils in regions where leaching/runoff occurs, $\mathrm{kg} \mathrm{N} \mathrm{yr}^{-1}$.

$\mathrm{F}_{\mathrm{CR}}=$ amount of $\mathrm{N}$ in crop residues, $\mathrm{kg} \mathrm{N} \mathrm{yr}^{-1}$.

$\mathrm{Frac}_{L E A C H}=$ fraction of all $\mathrm{N}$ added to/mineralized in managed soils in regions where leaching/runoff occurs that is lost through leaching and runoff, $\mathrm{kg} \mathrm{N}(\mathrm{kg}$ of $\mathrm{N}$ additions) $)^{-1}$ default value 0.30 .

$\mathrm{EF}_{5}=$ emission factor for $\mathrm{N}_{2} \mathrm{O}$ emissions from $\mathrm{N}$ leaching and runoff, $\mathrm{kg} \mathrm{N}_{2} \mathrm{O}-\mathrm{N}$ (kg N leached and runoff)-1 Default value 0.0075 .

The amount of $\mathrm{N}$ in harvest residue was inferred according to current methodology [12] considering sugarcane average yield for harvested without burn areas as 66.18 ton $\mathrm{ha}^{-1}$. As ratio residue/yield ratio is close to $0.205,13.75$ ton $\mathrm{ha}^{-1}$ of above ground residues, having $1.27 \%$ of $\mathrm{N}$ content on it, was available for combustion [15].

Once the amount of $\mathrm{N}$ in each of those composts was know it is possible to infer the $\mathrm{N}_{2} \mathrm{O}$ emission due to the direct application of fertilizers, taking into account the emission factor given by IPCC (2006). This calculation simply converts $1 \%$ of the total $\mathrm{N}$ input to $\mathrm{N}_{2} \mathrm{O}$ emission [12].

Indirect emissions of $\mathrm{N}_{2} \mathrm{O}$ involves two different pathways, the first one is the volatilization of $\mathrm{N}$ as ammonium $\left(\mathrm{NH}_{3}\right)$ and oxides of $\mathrm{N}\left(\mathrm{NO}_{\mathrm{x}}\right)$, and the following deposit of these gases and their products $\mathrm{NH}_{4}{ }^{+}$and $\mathrm{NO}_{3}{ }^{-}$in soil surface or lakes [12]. The nitrification and denitrification processes on soils transform some of these products to $\mathrm{N}_{2} \mathrm{O}$ returning back to atmosphere. According to the followed methodologies [12], 10\% of $\mathrm{N}$ input of synthetic fertilizers and $20 \%$ of $\mathrm{N}$ input of the organic compost is volatilized and transformed into $\mathrm{N}_{2} \mathrm{O}$, after nitrification and denitrification process on soils. Nevertheless, $1 \%$ of $\mathrm{N}$ applied on soils is transformed into $\mathrm{N}_{2} \mathrm{O}$, resulting in an indirect emission effect. Leaching and runoff are also secondary pathways that could result in $\mathrm{N}_{2} \mathrm{O}$ emissions, in some regions. It is assumed that $30 \%$ of total $\mathrm{N}$ applied as synthetic and organic fertilizer and unburned residues is leached or runoff but this can also return as $\mathrm{N}_{2} \mathrm{O}$ by an emission factor of 0.0075 , (or 0.75\%)[12]. 


\section{$\mathrm{CO}_{2}$ emissions due lime application}

The lime used during 2006/2007 season was the dolomite one $\mathrm{CaMg}\left(\mathrm{CO}_{3}\right)_{2}$, totalizing 25,883 ton applied in 11,423 ha (2.27 ton ha-1). For those it was considered an emission factor of 0.13 ton of $\mathrm{CO}_{2}$ per ton of dolomite lime applied [12].

\section{Emissions from mobile combustion}

In this scope only motors powered by diesel were took into account for emission due to fossil fuel combustion (Equation 5), including company proper machinery, the transport of sugarcane stalks to the mills and all supplies within the company boundary and labor transport, totalizing 7,058,709 liters. For the third part transport (sugarcane stalks, supplies and labors) it was considered only the annual consumption of diesel $(2,526,761 \mathrm{l})$ totalizing $9,585,470$ liters of diesel used to calculation.

Data of diesel fleet was obtained by the company mechanization sector according to a very careful control of vehicles and its fuel consumption and traveled distance per year (kilometers year ${ }^{-1}$ ), being $25.77 \%$ of trucks and buses, $52.22 \%$ of agricultural machinery and $22.01 \%$ of cars powered by ethanol. The data from sugar transport after company's boundary were not considered. The total fleet of cars used in the production cycle is powered by the same ethanol produced by the mill, hence it's assumed that the ethanol GHG emissions $\left(\mathrm{CO}_{2}\right)$ is reabsorbed in the next crop cycle and not accounted. The mobile sources were classified considering vehicles per category and manufacturing year, motor power and traveled distance per vehicle during the study (2006/2007 season).

Estimations of the GHG emission related to fossil fuel use in this study considered direct and indirect emissions of $\mathrm{CO}_{2}, \mathrm{CO}, \mathrm{CH}_{4}, \mathrm{~N}_{2} \mathrm{O}$ and NMVOC, according to the Brazilian Inventory recommendations [41]. Emission factors applied were also established (Air Control Program by Auto Motors Vehicles Pollution)/CETESB [25] in association with IBAMA (Brazilian Institute of Environment), considering type of fuel and vehicles. The methodology takes into account four steps: first it is considered data from fleet per vehicle category and second, the use of diesel, distributed by categories, and distance traveled. The next steps were to establish the emission factors, considering each vehicle, each vehicle's GHG emission per gas, and the conversion to $\mathrm{CO}_{2}$ eq using an Excel worksheet to arrange and calculate all results and determine total emissions per vehicle and the total GHG amount. To determine the diesel emission factors it was used diesel density as $852 \mathrm{~g} \mathrm{liter}^{-1}$ and specific consume of $195 \mathrm{~g}$ $\mathrm{kWh}^{-1}$, data from Brazilian fuel. The emission factors ( $\mathrm{g}$ liter $^{-1}$ ) used in this report was established in 06 phases according to vehicles manufacturing year.

$$
\begin{aligned}
\mathrm{E}_{\mathrm{g}, \mathrm{t}}=\mathrm{EF}_{\mathrm{g}, \mathrm{t}} \times \mathrm{FCt} \\
\mathrm{E}_{\mathrm{g}, \mathrm{t}}=\text { emission of gas } g \text { by fleet year/model } t . \\
\mathrm{EF}_{\mathrm{g}, \mathrm{t}}=\text { emission factor of gas gfrom vehicle's year } t \text {; }(\mathrm{g} \mathrm{L}- \\
\mathrm{FC}, \mathrm{t}=\text { Fuel consumption per vehicle's year } t \text { (liters). }
\end{aligned}
$$

Competing interests

The authors declare that they have no competing interests.

\section{Authors' contributions}

All authors participated in detailed discussions that led to this review paper. EBF conceived the document design and coordination, calculated the results and drafted the manuscript. ARP originally contributed to data analyses, interpretation, drafting and editing the manuscript. RR and NLSJ provided intellectual input on available data and previous analyses, and on the synthesis, presentation and interpretation needed for this review. All authors read and approved the final manuscript.

\section{Acknowledgements}

We are grateful to Fundação de Amparo à Pesquisa do Estado de São Paulo (FAPESP), Conselho Nacional de Desenvolvimento Científico e Tecnológico (CNPq) and Coordenação de Aperfeiçoamento de Pessoal de Nível Superior (CAPES) for support.

\section{Author Details}

FCAV/UNESP, Departamento de Ciências Exatas,.Via de acesso Prof. Paulo D. Castellane s/n. 14884-900, Jaboticabal, São Paulo, Brazil

Received: 11 March 2010 Accepted: 17 June 2010

Published: 17 June 2010

\section{References}

1. Intergovernmental Panel on Climate Change - IPCC. 2007: Climate Change 2007: The Physical Science Basis. In Contribution of Working Group I to the Fourth Assessment Report of the Intergovernmental Panel on Climate Change Edited by: Solomon S, Qin D, Manning M, Chen Z, Marquis M, Averyt KB, Tignor M, Miller HL. Cambridge University Press, Cambridge, United Kingdom and New York, NY, USA; 2007:996.

2. Umemiya C: Improving GHG inventories by regional information exchange: a report from Ásia. Carbon Balance and Management 2006, 1:9.

3. Cerri CEP, Sparovek G, Bernoux M, Easterling WE, Melillo M, Cerri CC: Tropical Agriculture and Global Warming: Impacvts and Mitigations Options. Scientia Agricola 2007, 64(n.1):83-99.

4. IPCC: Revised 1996 IPCC Guidelines for National Greenhouse Gas Inventories. Bracknell; 1996.

5. Oliveira PHF, Artaxo P, Pires C, de Lucca S, Procopio A, Holben B, Schafer J, Cardoso LF, Wofsy SC, Rocha HR: The effects of biomass burning aerosols and clouds on the $\mathrm{CO}_{2}$ flux in Amazonia. Tellus 2007, 59B:338-349.

6. Cançado JED, Saldiva PHN, Pereira LAA, Lara LBLS, Artaxo P, Martinelli LA, Arbex MA, Zanobetti A, Alfesio LF, Braga ALF: The Impact of Sugar CaneBurning Emissions on the Respiratory System of Children and the Elderly. Environmental Health Perspectives 2006, 114:5.

7. Goldemberg J, Coelho ST, Guardabassi P: The sustainability of ethanol production from sugarcane. Energy Policy 2008, 36:2086-2097.

8. CONAB: Companhia Nacional de Abastecimento. Acompanhamento de Safra. 2009 [http://www.conab.gov.br/conabweb/download/safra/ 1 cana de acucar.pdf]. Accessed in: 20 jun 2009

9. Food and Agriculture Organization and IFA: Global estimation of gaseous emission of $\mathrm{NH}_{3}, \mathrm{NO}$ and $\mathrm{N}_{2} \mathrm{O}$ from agricultural land. 2001 [ftp:// ftp.fao.org/agl/agll/docs/globest.pdf]. FAO, Rome, Italy Accessed in: 12 sep 2009

10. Goldemberg J: Biomassa e energia. Quimica Nova 2009, 32(3):582-587.

11. Cerri CC, Maia SMF, Galdos MV, Cerri CEP, Feigl BJ, Bernoux Mk: Brazilian greenhouse gas emissions: the importance of agriculture and livestoc. Scientia Agricola 2009, 66(6):831-843. 
12. Intergovernmental Panel on Climate Change - IPCC. 2006. IPCC: Guidelines for National Green House Gas Inventories, Prepared by the National Greenhouse Gas Inventories Programme. Edited by: Eggleston HS, Buendia L, Miwa K, Ngara T, Tanabe K. Japan: IGES; 2006. Chapter 11, $\mathrm{N}_{2} \mathrm{O}$ emissions from managed soils, and $\mathrm{CO}_{2}$ emissions from lime and urea application. Chapter 2 Generic methodologies applicable to multiple land-use categories

13. Ministérioda Ciência e Tecnologia - MCT: Primeiro inventário brasileiro de emissões antrópicas de gases de efeito estufa, relatórios de referência, ministério da ciência e tecnologia, emissões de gases de efeito estufa no setor energético por fontes móveis. 2006 [http:// www.mct.gov.br/index.php/content/view/57270.html]. Accessed in: 10 feb.2009

14. Soares $L H$, de B, Alves BJR, Urquiaga S, Boddey MR: Mitigação das emissões de Gases de Efeito Estufa pelo Uso de Etanol da Cana-deaçúcar Produzido no Brasil. 2009:14 [http://www.cnpab.embrapa.br/ publicacoes/download/cit027.pdf. Seropédia: Embrapa (Circular Técnica, 27). Accessed in: 06 oct 2009

15. Oliveira de MED, Vaughan BE, Edward Jr: Ethanol as Fuel: Energy, Carbon Dioxide Balances, and Ecological Footprint. BioScience 2005, 55:57.

16. Macedo IC, Seabra JEA, Silva JEAR: Green house gases emissions in the production and use of ethanol from sugarcane in Brazil: The 2005/2006 averages and a prediction for 2020. Biomass and Bioenergy 2008, 32:582-595.

17. National Biodiesel Board: [http://www.biodiesel.org/]. Accessed in 20/09/ 2009. Imperial College

18. Koga $\mathrm{N}$, Tsuruta $\mathrm{H}$, Tsuji $\mathrm{H}$, Nakanoa $\mathrm{H}$ : Fuel consumption-derived $\mathrm{CO}_{2}$ emissions under conventional and reduced tillage cropping systems in northern Japan. Agriculture, Ecosystems and Environment 2003, 99:213-219.

19. Davidson EA, Microbial Production and Consumption of Greenhouse Gases: Methane, Nitrogen oxides, and Halomethanes, American Society of Microbiology: Fluxes of nitrous oxide and nitric oxide from terrestrial ecosystems. Edited by: Rogers JE, Whitman WB. Washington DC; 1991:219-235.

20. Conrad R: Metabolism of nitric oxide in soil and soil microorganisms and regulation of flux into the atmosphere. In Microbiology of Atmospheric Edited by: Murrell JC, Donovan PK. Springer-Verlag, Berlin, Heidelberg; 1996:167-203. Trace Gases, NATO ASI Series. I 39

21. Kroeze C, Mosier A, Bouwman L: Closing the global N2O budget: A retrospective analysis 1500-1994. Global Biochem Cycles 1999, 13(1):1-8.

22. Bouwman AF, Lee DS, Asman WAH, Dentener FJ, Van Der Hoek KW, Olivier JGJ: A global high-resolution emission inventory for ammonia. Global Biochem Cycles 1997, 11(4):561-587.

23. Sommer SG, Hutchings NJ: Techniques and strategies for the reduction of ammonia emissions from agriculture. Water, Air Soil Pollut 1995, 85:237-248

24. Mosier AR, Duxbury JM, Freney JR, Heinemeyer O, Minami K: Nitrous oxide emissions from agricultural fields: Assessment, measurement and mitigation. Plant and Soil 1996, 181:01.

25. Robertson GP: Nitrogen use efficiency in row-crop agriculture. Crop nitrogen use and crop nitrogen loss. In Ecology in Agriculture Edited by: Jackson L. Academic Press. New York; 1997:347-365.

26. Majundar D, Rastogi M, Kumar S, Pathack M, Jain C, Kumar U: Nitrous oxide emission from an alluvial soil with different nitrogenous fertilizers and nitrogen levels. Indian Soc Soil Science 2001, 48:732-741.

27. Brentrup F, Kusters K, Lammel J: Application of the Life Cycle Assessment methodology to agricultural production: an example of sugar beet production with different forms of nitrogen fertilizers. European Journal of Agronomy 2001, 14:221-233.

28. Seabra JEA, Macedo IC: Balanço de energia e emissões de GEE na produção do açúcar e álcool orgânico na usina São Francisco. 2008 [http://www.nativealimentos.com.br/upload/Inventario CO2.pdf].

29. Gifford RM: Energy in different agricultural systems: renewable and non-reneweble sources. In Energy and Agriculture Edited by: Stanhill G. Berlim: Springer-Verlag; 1984:84-112. Accessed in: 03 dec 2007

30. Rezende AS, Santos AO, Gondim A, Xavier RP, Coelho CHM, Oliveira de OC, Alves BJR, Boddey RM, Urquiaga S: EMBRAPA. Efeito Estufa e o Seqüestro de Carbono em Sistemas de Cultivo com Espécies Florestais e na Cultura de Cana-de-açúcar. 2001:24. Documento num. 133
31. Ripoli TC, Molina WF JR, Stupiello JP, Nogueira MC, Saccomano JB: Potencial energético de resíduos de cosecha de la cana verde. Piracicaba: STAB 1991.

32. MacCarty N, Ogle D, Still D, Bond T, Roden C, Willson B: Laboratory comparison of the global-warming potential of six categories of biomass cooking stoves. Aprovecho Research Center 2007:6.

33. Ronquim CC: Dinâmica espaço temporal do carbono aprisionado na fitomassa dos agroecossistemas do Nordeste do Estado de São Paulo. Campinas: Embrapa Monitoramento por Satélite; Ribeirão Preto: ABAGRP, 52 2007 [http://www.abagrp.org.br/media/uploads/pdf/ Iv fitomassa nesp.pdf]. Accessed in: 06 nov 2007

34. Ripoli TC, Stupiello JP, Caruso JGB, Zotelli H, Amaral JR: Efeito da queima na exsudação dos colmos: resultados preliminares. 1996. Congresso da sociedade dos técnicos açucareiros e alcooleiros do Brasil, 6, 1996, Maceió. Anais. Piracicaba: STAB

35. Gheller ACA: Variedades de cana-de-açúcar cultivadas no Estado de São Paulo em 1995 - Censo varietal. 1996. Congresso Nacional da Sociedade dos Técnicos Açucareiros e Alcooleiros do Brasil - STAB, 6 , Maceió, nov., Anais. Piracicaba: STAB

36. Levine J: Global biomass burning: a case study of the gaseous and particulate emissions released to the atmosphere during the 1997 fires in Kalimantan and Sumatra, Indonesia, in Biomass Burning and its Inter-relationships with the Climate System. Edited by: Innes J, Beniston M, Verstraete M. Kluwer Academic Publishers: Dordrecht; 2000:15-31.

37. Gullett B, Touati A, Huwe J, Akk A: Emissions from Simulated Sugarcane Field Burning. Environmental Science \&Technology 2006, 40:20. PCDD and PCDF

38. Andrea MO, Merlet P: Emission of trace gases and aerosols from biomass burning. Global Biogeochemical Cycles 2001, 15:955-966.

39. Macedo IC, Leal MLRV, da Silva Jear: Balanço das emissões de gases de efeito estufa na produção e uso do etanol no Brasil. Secretaria do Meio Ambiente, Governo de São Paulo 2004 [http://www.unica.com.br/ download.asp?mmdCode=76A95628-B539-4637-BEB3-C9C48FB29084]. Accessed in: 05 nov 2008

40. Elia Neto A, Nakahodo T: Caracterização físico-química da vinhaça. Centro de Tecnologia Canavieira, Piracicaba, São Paulo, Brazil; 1995.

41. Proconve. Control Program of air pollution by vehicles Programa de Controle da Poluição do Ar por Veículos Automotores: 2006 [http:// www.ibama.gov.br/proconve/obter cagn.php]. Accessed in: 07 dec. 2008

\section{doi: 10.1186/1750-0680-5-3}

Cite this article as: de Figueiredo et al., Greenhouse gas emission associated with sugar production in southern Brazil Carbon Balance and Management 2010, $5: 3$

\section{Submit your next manuscript to BioMed Centra and take full advantage of:}

- Convenient online submission

- Thorough peer review

- No space constraints or color figure charges

- Immediate publication on acceptance

- Inclusion in PubMed, CAS, Scopus and Google Scholar

- Research which is freely available for redistribution 